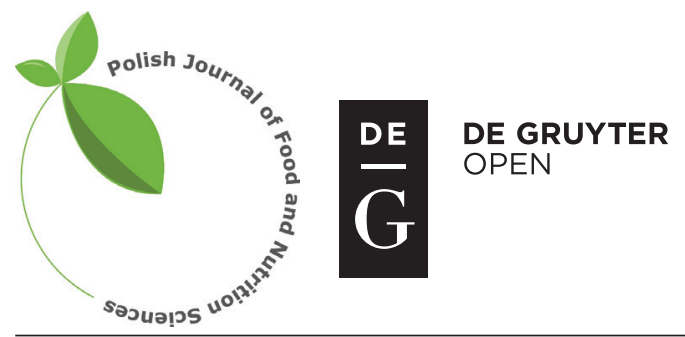

Pol. J. Food Nutr. Sci., 2017, Vol. 67, No. 1, pp. 59-66 DOI: $10.1515 /$ pjfns-2016-0021

Original article

Section: Food Quality and Functionality

\title{
Comparison of the Effect of New Spice Freon Extracts Towards Ground Spices and Antioxidants for Improving the Quality of Bulgarian-Type Dry-Cured Sausage
}

\author{
Dessislav Kostadinov Balev ${ }^{1}$, Neno Stefanov Nenov ${ }^{2}$, Stefan Georgiev Dragoev ${ }^{1}$, Kiril Petrov Vassilev ${ }^{1}$, Dessislava \\ Borislavova Vlahova-Vangelova ${ }^{1 *}$, Sholpan Baydildaevna Baytukenova ${ }^{3}$, Farida Haripovna Smolnikova ${ }^{3}$
}

\author{
${ }^{1}$ Department of Meat and Fish Technology, Technological Faculty, University of Food Technologies, \\ 26 Martisa Blvd., 4000 Plovdiv, Bulgaria; \\ ${ }^{2}$ Department of Heat Technique, Technical Faculty, University of Food Technologies, Plovdiv, Bulgaria; \\ ${ }^{3}$ Department of Technology of Food Products and Products of Light Industry, Shakarim State University of Semey, \\ Semey, Kazakhstan
}

Key words: black pepper, cumin, taxifolin, rosemary extract, dry-cured sausages

Ground spices are a source of hazards for dry-fermented meat products. Since dry-cured sausages are not subjected to heat treatment, there is a high risk of microbial cross-contamination and physical impurities. The aim of this study was to determine effects of the replacement of $3 \mathrm{~g} / \mathrm{kg}$ of ground black pepper (Piper nigrum L.), and cumin (Cuminum cyminum) with their aliquots of new freon extracts, and compare them with the effect of $0.2 \mathrm{~g} / \mathrm{kg}$ antioxidant addition (taxifolin extract from Siberian larch (Larix sibirica Ledeb), rosemary (Rosmarinus officinalis L.) extract, and butylated hydroxytoluene) on sensory properties, color stability, proximate composition, free amino nitrogen and pH of Bulgarian-type dry-cured „Sudjuk“ sausages. The replacement of natural ground spices with aliquots of their extracts improved sensory properties and stabilized the color characteristics of the final product during 30 days of storage at $0-4^{\circ} \mathrm{C}$. The addition of $0.2 \mathrm{~g} / \mathrm{kg}$ rosemary extract was as effective as the addition of freon extracts on the overall assessment to the 14th day of the experiment. It was determined that the addition of antioxidants or spice extracts had no significant effect on proximate composition, $\mathrm{pH}$, and free amino nitrogen accumulation of the "Sudjuk". The addition of $0.2 \mathrm{~g} / \mathrm{kg}$, taxifolin or rosemary extracts and butylated hydroxytoluene was not so efficient in improving the sensory properties and color stabilization in comparison to the new freon spice extracts. The examined spice extracts can be successfully used to improve the quality of "Sudjuk" sausages.

\section{INTRODUCTION}

The quality characteristics of dry-cured sausages are based on physicochemical, biochemical and microbiological changes during their aging, drying and refrigeration [Rohlik \& Pipek, 2013]. Chemical substances produced by proteolysis [Hughes et al., 2002] and lipolysis [Zanardi et al., 2002], microbial fermentation [Cabeza et al., 2009], lipid oxidation [Curt et al., 2002] or addition of spices and salts form the characteristic taste and aroma of this group of meat products [Marco et al., 2004]. The production of free amino acids and short chain peptides was considered an important element in flavour enhancing of dry-fermented sausages [Misharina et al., 2001].

Natural ground spices are a source of microbiological and physical hazards for meat products [Dorman \& Deans, 2000]. Since dry-cured sausages are not subjected to heat treatment, there is a high risk of microbial cross-contamination and physical impurities [Cabeza et al., 2009]. Because the volatile essential oil components from pre-ground spices take off during their storage, they do not contribute to a suf-

\footnotetext{
* Corresponding Author: Tel.: +385 312243 19;

E-mail: desislava_vangel ${ }^{\circ} v a @ a b v . b g\left(\right.$ D. B B $^{\circ}$ rislav ${ }^{\circ}$ va Blah $^{\circ}$ va-Vangel $\left.{ }^{\circ} v a\right)$
}

ficient degree to the development of the desired sausage taste and aroma [Marco et al., 2004]. Synthetic antioxidants such as butylated hydroxyanisole (BHA), butylated hydroxytoluene (BHT), and tert-butylhydroquinone (TBHQ) are added as inhibitors of lipid oxidation in meat products, but if used in high concentrations they have toxic effects [van Esch, 1986; Balev et al., 2005; Fasseas et al., 2008]. Increasing interest in natural food consumption requires replacing the synthetic antioxidants with natural ingredients that improve the quality and nutritional value of the products [Fasseas et al., 2008]. Some studies have demonstrated that shelf-life and meat quality can be improved by using natural antioxidants in some stages of sausage processing [Balev et al., 2005; Bakalivanova \& Kaloyanov, 2014; Rohlik \& Pipek, 2013]. Natural antioxidants have been used instead of synthetic antioxidants to retard lipid oxidation in foods, and to improve their nutritional value [Velasco \& Williams, 2011]. Many herbs, spices, and their extracts have been reported as having high antioxidant capacity [Velasco \& Williams, 2011; Rohlik \& Pipek, 2013]. The addition of herbs, spices or their extracts to the dry-fermented sausages enhances their sensory properties and extends their shelf-life [Curt et al., 2002; Suhaj, 2006]. The antioxidant activity of these plants is attrib- 
uted to their phenolic compound content, which includes volatile essential oils [Velasco \& Williams, 2011; Bakalivanova \& Kaloyanov, 2014]. Spices can be added to foods in several forms: in a natural state, ground or as extracts. Depending on the solvent used, the spice extracts could be methanol, ethanol, acetone/water or oil mixtures [Suhaj, 2006].

In the available literature we did not find any information about the application of spice extracts obtained using freon extraction. Therefore, the objective of this study was to replace the $3 \mathrm{~g} / \mathrm{kg}$ of ground black pepper (Piper nigrum L.), and cumin (Cuminum cyminum) with their aliquots from freon extracts (E) newly developed at our University, and to compare with additions of $0.2 \mathrm{~g} / \mathrm{kg}$ butylated hydroxytoluene (B), taxifolin extract from Siberian larch (Larix sibirica Ledeb) (T), or rosemary (Rosmarinus officinalis L.) extract (R), and to investigate their effects on sensory properties, color stability, proximate composition, free amino nitrogen and $\mathrm{pH}$ of Bulgarian-type dry-cured sausages "Sudjuk".

\section{MATERIALS AND METHODS}

\section{Materials}

The beef shoulder and topside, and pork back fat were used in sausage processing. The meat raw materials were supplied by Unitemp Ltd (Voyvodinovo village, Plovdiv district, Bulgaria). The carcasses were deboned and sorted.

The nitrite salt which was a mixture of sodium chloride with $0.4 \%$ sodium nitrite (E 250) was purchased from BBT Ltd (Sofia, Bulgaria). Bacterial starter culture Bactoferm PI and sugars were supplied by Christian Hansen A/S (Horsholm, Denmark). The extract from Siberian larch was manufactured and delivered by Vitalife Ltd (Moscow, Rus-

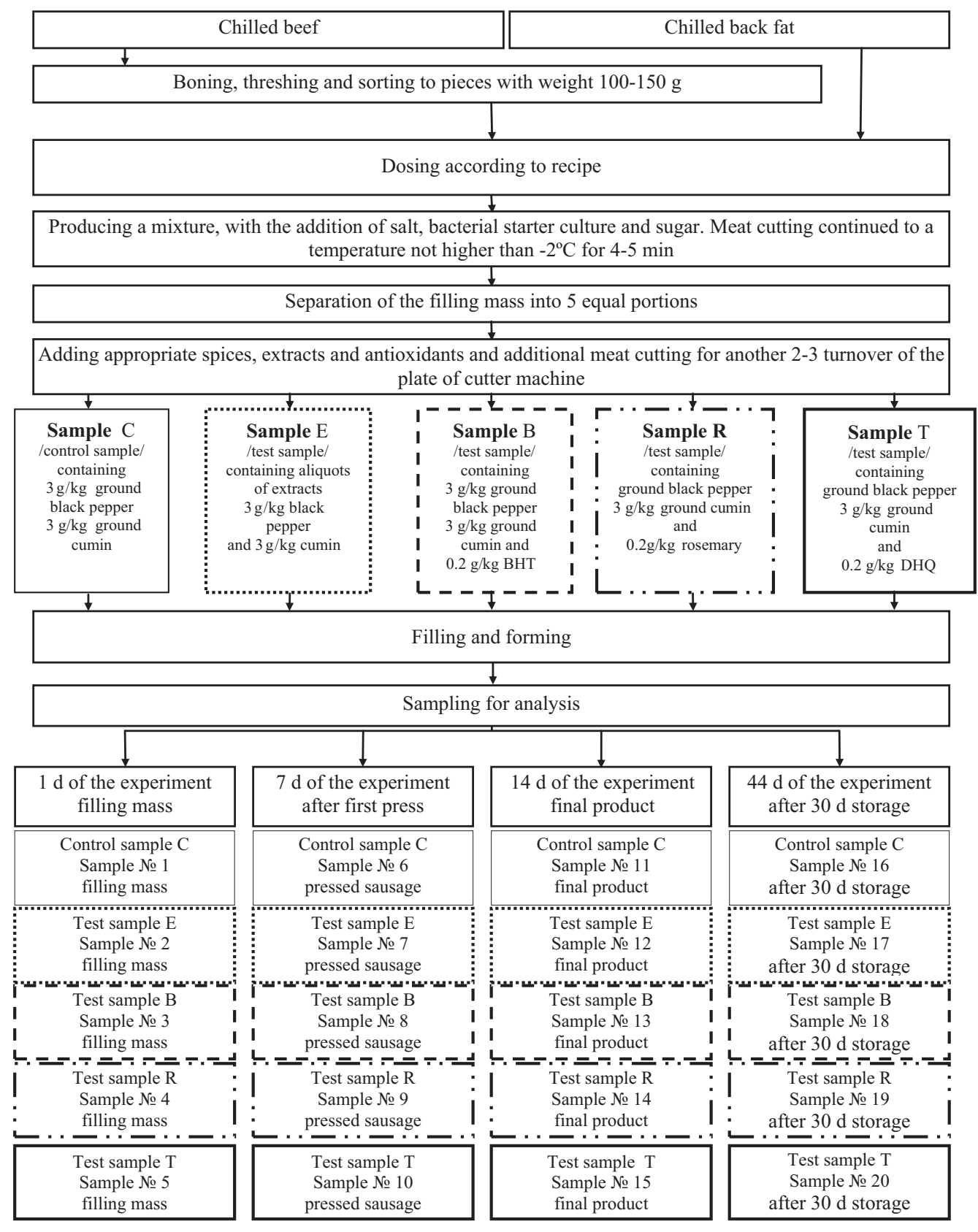

FIGURE 1. Experimental design. 
sia). The rosemary extract was processed in Aromena Ltd (Sofia, Bulgaria). Black pepper and cumin ground at $-80^{\circ} \mathrm{C}$ and packed under modified atmosphere in light- and gastight hermetically sealed packs, were supplied by Kresona Ltd (Buzovgrad village, district Kazanluk, Bulgaria). The black pepper and cumin extracts were produced at the University of Food Technologies (Plovdiv, Bulgaria) from the same spice sources. The extraction was carried out with non-polar food grade liquefied gas tetrafluoroethane (Freon 134 ${ }^{\mathrm{a}}$, CAS number 811-97-2) (Freon). Freon 134 a is permitted as a solvent for extraction of flavorings added to foods and is harmless to the human body. The final product after extraction is completely free of the solvent content. Separated freon is collected from the system and can be used again [Nenov, 2006].

The spices were grinded separately in an attrition mill to a size of $0.15-0.25 \mathrm{~mm}$. The extracts were obtained in a $1 \mathrm{dm}^{3}$ volume laboratory extractor for 50-60 min at temperature of $20-25^{\circ} \mathrm{C}$ and pressure of $570-650 \mathrm{kPa}$.

\section{Experimental design}

The sample preparation and experimental design are presented in Figure 1. The final product (on $14^{\text {th }}$ day of the experiment) was vacuum-packed. A packaging machine Yang SR1, model Polaris VAC, Ductto (Como via al Bassone, Italy) was used. The vacuum-packed samples were stored for 30 days at $0-4^{\circ} \mathrm{C}$ to the $44^{\text {th }}$ day of the experiment.

\section{Sensory analysis}

The sensory characteristics of the surface of sectional view, color, aroma, taste and consistence were judged after opening the packages. A panel consisting of five members with proven tasting abilities [Meilgaard et al., 2006] was used. The samples were scored using 1 to 9 scales as follows: 9 - excellent; 8 - very good; 7 - good; 6 - acceptable; 5 - satisfactory; 4 - slightly unsatisfactory; 3 - highly unsatisfactory; 2 - bad; 1 - unacceptable. The panelists were passed the triangular test for differentiation of fresh and rancid sausage taste, odor, and color.

\section{Evaluation of color properties}

Colorimeter CR 410 (Konica Minolta Holding, Inc., Ewing, NJ, USA), purchased from Sending Inc. (Tokyo, Japan) was used to evaluate the CIE L*, $a^{*}, b^{*}, C$, and $\mathrm{H}$ color properties [Hunt et al., 2012].

\section{Estimation of proximate composition}

The moisture content was determined by drying at $105^{\circ} \mathrm{C}$ [Kirkbright et al., 1975]. The ash content was determined after samples drying at $102^{\circ} \mathrm{C}$ and heating in a muffle oven at $525^{\circ} \mathrm{C}$ for $4 \mathrm{~h}$ [Stojković et al., 2013]. The protein content was analyzed with the Kjeldahl method using Keltec Auto 1030 analyzer (Tecator, Sweden). The protein content was calculated by a conversion factor 6.25 [King \& Sebranek, 1993]. The total lipids were determined following the Soxhlet procedure [Jensen, 2007].

\section{Determination of free amino nitrogen}

The free amino nitrogen was determined with the $\mathrm{S} \varnothing$ rensen method [Tešanović et al., 2011] based on the formol titration of amino acids from meat extract samples with formaldehyde in the presence of potassium hydroxide.

TABLE 1 . Sensory scores of the dry-cured sausages "Sudjuk" after manufacturing and 30 days of storage at $0-4{ }^{\circ} \mathrm{C}$.

\begin{tabular}{|c|c|c|c|c|c|c|}
\hline Sample & $\begin{array}{c}\text { Surface } \\
\text { of sectional view }\end{array}$ & Color & Consistence & Aroma & Taste & $\begin{array}{c}\text { Overall } \\
\text { acceptability }\end{array}$ \\
\hline \multicolumn{7}{|c|}{$\begin{array}{l}\text { Sensory scores of the samples on the } 14^{\text {th }} \text { day of the experiment } \\
\text { (final product immediately after manufacturing) }\end{array}$} \\
\hline $\mathrm{C}$ & $7.78^{c} \pm 0.24$ & $7.65^{\mathrm{c}} \pm 0.29$ & $7.44^{\mathrm{c}} \pm 0.27$ & $7.98^{z} \pm 0.23$ & $6.84^{b} \pm 0.27$ & $7.50^{c} \pm 0.28$ \\
\hline $\mathrm{E}$ & $8.93^{\mathrm{e}} \pm 0.25$ & $9.00^{\mathrm{e}} \pm 0.00$ & $9.00^{\mathrm{f}} \pm 0.00$ & $8.58^{\mathrm{e}} \pm 0.22$ & $7.99^{\mathrm{d}} \pm 0.25$ & $8.67^{\mathrm{e}} \pm 0.26$ \\
\hline B & $8.06^{\mathrm{d}} \pm 0.29$ & $7.70^{c} \pm 0.22$ & $8.40^{\mathrm{e}} \pm 0.23$ & $8.40^{\mathrm{e}} \pm 0.28$ & $8.14^{\mathrm{d}} \pm 0.25$ & $8.11^{\mathrm{d}} \pm 0.21$ \\
\hline $\mathrm{R}$ & $8.28^{\mathrm{d}} \pm 0.27$ & $7.61^{\mathrm{c}} \pm 0.21$ & $8.16^{\mathrm{d}} \pm 0.28$ & $9.00^{\mathrm{f}} \pm 0.00$ & $8.35^{\mathrm{e}} \pm 0.29$ & $8.25^{\mathrm{e}} \pm 0.26$ \\
\hline $\mathrm{T}$ & $7.78^{c} \pm 0.29$ & $7.61^{\mathrm{c}} \pm 0.21$ & $8.04^{\mathrm{d}} \pm 0.20$ & $8.58^{\mathrm{e}} \pm 0.17$ & $8.06^{\mathrm{d}} \pm 0.24$ & $7.97^{\mathrm{d}} \pm 0.25$ \\
\hline \multicolumn{7}{|c|}{$\begin{array}{l}\text { Sensory scores of the samples on the } 44^{\text {th }} \text { day of the experiment } \\
\text { (Sudjuk refrigeration stored } 30 \text { days after production) }\end{array}$} \\
\hline $\mathrm{C}$ & $7.00^{\mathrm{a}} \pm 0.27$ & $6.50^{\mathrm{a}} \pm 0.28$ & $6.08^{\mathrm{a}} \pm 0.28$ & $6.16^{\mathrm{a}} \pm 0.23$ & $6.67^{b} \pm 0.22$ & $5.83^{a} \pm 0.25$ \\
\hline $\mathrm{E}$ & $7.33^{b} \pm 0.29$ & $8.17^{\mathrm{d}} \pm 0.27$ & $7.33^{c} \pm 0.27$ & $7.42^{c} \pm 0.29$ & $7.42^{c} \pm 0.29$ & $7.42^{c} \pm 0.29$ \\
\hline B & $7.42^{b} \pm 0.26$ & $7.42^{c} \pm 0.29$ & $6.50^{\mathrm{b}} \pm 0.28$ & $7.50^{c} \pm 0.21$ & $7.50^{c} \pm 0.21$ & $6.83^{\mathrm{b}} \pm 0.22$ \\
\hline $\mathrm{R}$ & $7.17^{\mathrm{a}} \pm 0.28$ & $7.00^{\mathrm{b}} \pm 0.28$ & $6.50^{\mathrm{b}} \pm 0.26$ & $6.08^{a} \pm 0.28$ & $6.33^{a} \pm 0.29$ & $6.75^{\mathrm{b}} \pm 0.20$ \\
\hline $\mathrm{T}$ & $7.00^{\mathrm{a}} \pm 0.21$ & $7.67^{c} \pm 0.23$ & $6.75^{b} \pm 0.20$ & $6.67^{b} \pm 0.28$ & $6.92^{\mathrm{b}} \pm 0.22$ & $6.58^{\mathrm{b}} \pm 0.29$ \\
\hline
\end{tabular}

C-control sample with $3 \mathrm{~g} / \mathrm{kg}$ of ground black pepper (Piper nigrum L.) and cumin (Cuminum cyminum); E- test sample with freon extracts of ground black pepper (Piper nigrum L.), and cumin (Cuminum cyminum); B- test sample with $3 \mathrm{~g} / \mathrm{kg}$ of ground black pepper (Piper nigrum L.), and cumin (Cuminum cyminum) and $0.2 \mathrm{~g} / \mathrm{kg}$ butylated hydroxytoluene addition; R- test sample with $3 \mathrm{~g} / \mathrm{kg}$ of ground black pepper (Piper nigrum L.), and cumin (Cuminum cyminum) and $0.2 \mathrm{~g} / \mathrm{kg}$ rosemary (Rosmarinus officinalis L.) extract addition; T- test sample with $3 \mathrm{~g} / \mathrm{kg}$ of ground black pepper (Piper nigrum L.), and cumin (Cuminum cyminum) and $0.2 \mathrm{~g} / \mathrm{kg}$ taxifolin extract from Siberian larch (Larix sibirica Ledeb) addition.

The data for $14^{\text {th }}$ day and $44^{\text {th }}$ day were analyzed with the same ANOVA analysis. Data were expressed as Mean \pm SD $(n=9)$. a, b, c, d, e, $f-$ Means in the column with different subscript letters are significantly different $(\mathrm{p} \leq 0.05)$. 
TABLE 2. Color characteristics of the dry-cured sausages "Sudjuk" during processing, after manufacturing and 30 days of storage at $0-4{ }^{\circ} \mathrm{C}$.

\begin{tabular}{|c|c|c|c|c|c|}
\hline Sample & $\begin{array}{l}\text { Brightness of the color } \\
\text { (L*) }\end{array}$ & $\begin{array}{l}\text { Red component } \\
\text { of the color } \\
\left(a^{*}\right)\end{array}$ & $\begin{array}{l}\text { Yellow component } \\
\text { of the color } \\
\left(\mathrm{b}^{*}\right)\end{array}$ & \begin{tabular}{|c|} 
Chromaticity of the tone \\
(C)
\end{tabular} & $\begin{array}{l}\text { Color saturation / } \\
\text { Chroma/ } \\
(\mathrm{H})\end{array}$ \\
\hline \multicolumn{6}{|c|}{$\begin{array}{l}\text { Color characteristics of the samples on the } 7^{\text {th }} \text { day of experiment } \\
\text { (semimanufactured sausages in the process of drying and ripening after the first press) }\end{array}$} \\
\hline $\mathrm{C}$ & $35.77^{\mathrm{e}} \pm 1.51$ & $16.66^{\mathrm{c}} \pm 1.34$ & $9.67^{b} \pm 1.02$ & $19.26^{\mathrm{c}} \pm 1.33$ & $30.13^{b} \pm 1.02$ \\
\hline $\mathrm{E}$ & $37.94^{\mathrm{g}} \pm 1.23$ & $19.51^{\mathrm{f}} \pm 1.27$ & $11.19^{\mathrm{d}} \pm 1.15$ & $22.49^{\mathrm{f}} \pm 1.44$ & $29.83^{b} \pm 1.00$ \\
\hline B & $42.60^{\mathrm{j}} \pm 1.89$ & $14.92^{b} \pm 1.19$ & $9.92^{\mathrm{b}, \mathrm{c}} \pm 1.00$ & $17.92^{\mathrm{a}} \pm 1.21$ & $33.62^{\mathrm{d}} \pm 1.13$ \\
\hline $\mathrm{R}$ & $36.70^{\mathrm{f}} \pm 1.33$ & $16.69^{\mathrm{c}} \pm 1.38$ & $10.33^{\mathrm{c}} \pm 1.13$ & $19.63^{\mathrm{c}} \pm 1.34$ & $31.77^{\mathrm{c}} \pm 1.22$ \\
\hline $\mathrm{T}$ & $36.59^{\mathrm{f}} \pm 1.09$ & $17.67^{\mathrm{d}} \pm 1.21$ & $10.99^{\mathrm{c}} \pm 1.18$ & $20.81^{\mathrm{d}} \pm 1.40$ & $31.90^{c} \pm 1.28$ \\
\hline \multicolumn{6}{|c|}{ Color characteristics of the samples on the $14^{\text {th }}$ day of experiment } \\
\hline $\mathrm{C}$ & $38.56^{\mathrm{h}} \pm 1.54$ & $14.54^{\mathrm{a}} \pm 1.26$ & $9.66^{\mathrm{b}} \pm 1.11$ & $17.46^{\mathrm{a}} \pm 1.42$ & $33.59^{\mathrm{d}} \pm 1.05$ \\
\hline $\mathrm{E}$ & $38.49^{\mathrm{h}} \pm 1.26$ & $16.06^{\mathrm{c}} \pm 1.17$ & $7.87^{\mathrm{a}} \pm 0.97$ & $17.88^{\mathrm{a}} \pm 1.37$ & $26.11^{\mathrm{a}} \pm 1.03$ \\
\hline B & $36.20^{\mathrm{f}} \pm 1.37$ & $15.06^{\mathrm{b}} \pm 1.32$ & $9.40^{b} \pm 1.01$ & $17.75^{\mathrm{a}} \pm 1.36$ & $31.99^{\mathrm{c}} \pm 1.12$ \\
\hline $\mathrm{R}$ & $35.02^{\mathrm{e}} \pm 1.19$ & $17.23^{\mathrm{c}, \mathrm{d}} \pm 1.24$ & $10.03^{\mathrm{b}, \mathrm{c}} \pm 1.17$ & $19.93^{\mathrm{c}} \pm 1.28$ & $30.21^{\mathrm{b}} \pm 1.24$ \\
\hline $\mathrm{T}$ & $32.35^{\mathrm{d}} \pm 1.22$ & $18.65^{\mathrm{e}} \pm 1.38$ & $10.83^{\mathrm{c}} \pm 1.12$ & $21.56^{\mathrm{e}} \pm 1.45$ & $30.15^{b} \pm 1.27$ \\
\hline \multicolumn{6}{|c|}{$\begin{array}{l}\text { Color characteristics of the samples on the } 44^{\text {th }} \text { day of experiment } \\
\text { (Sudjuk refrigeration stored } 30 \text { days after production) }\end{array}$} \\
\hline $\mathrm{C}$ & $27.20^{c} \pm 1.44$ & $14.70^{\mathrm{a}} \pm 1.18$ & $10.45^{\mathrm{c}} \pm 1.21$ & $18.43^{\mathrm{b}} \pm 1.39$ & $35.21^{\mathrm{d}} \pm 1.24$ \\
\hline $\mathrm{E}$ & $22.80^{b} \pm 1.11$ & $21.95^{\mathrm{g}} \pm 1.33$ & $16.14^{\mathrm{f}} \pm 1.29$ & $27.63^{\mathrm{h}} \pm 1.27$ & $35.54^{\mathrm{d}, \mathrm{e}} \pm 1.33$ \\
\hline B & $27.14^{c} \pm 1.35$ & $16.35^{\mathrm{c}} \pm 1.27$ & $11.53^{\mathrm{d}} \pm 1.30$ & $20.60^{\mathrm{d}} \pm 1.47$ & $34.83^{\mathrm{e}} \pm 1.37$ \\
\hline $\mathrm{R}$ & $23.95^{b} \pm 1.28$ & $18.68^{\mathrm{e}} \pm 1.30$ & $13.46^{\mathrm{e}} \pm 1.27$ & $24.03^{\mathrm{g}} \pm 1.43$ & $34.17^{\mathrm{d}} \pm 1.41$ \\
\hline $\mathrm{T}$ & $21.13^{\mathrm{a}} \pm 1.01$ & $17.93^{\mathrm{d}} \pm 1.25$ & $13.11^{\mathrm{e}} \pm 1.28$ & $22.64^{\mathrm{f}} \pm 1.39$ & $35.75^{\mathrm{f}} \pm 1.40$ \\
\hline
\end{tabular}

Sample description as under Table 1 . The data for $14^{\text {th }}$ day and $44^{\text {th }}$ day were analyzed with the same ANOVA analysis. Data were expressed as Mean $\pm \mathrm{SD}(\mathrm{n}=9)$. a, b, , , d, e, f, g- Means in the column with different subscript letters are significantly different $(\mathrm{p} \leq 0.05)$.

\section{Determination of $\mathrm{pH}$ value}

The $\mathrm{pH}$ value of the samples was determined by using pH-meter MS 2004 (Microsyst Ltd, Plovdiv, Bulgaria), equipped with a combined $\mathrm{pH}$ recorder S $450 \mathrm{CD}$ (Sensorex $\mathrm{pH}$ Electrode Station, Garden Grove, CA, USA) [Young et al., 2004].

\section{Microbiological analysis}

Sudjuk samples $(10 \mathrm{~g})$ were aseptically put to hermetically closed bags. The samples were homogenized for $2 \mathrm{~min}$ at $200 \mathrm{~min}^{-1}$ with $90 \mathrm{~mL}$ of $0.85 \%$ sodium chloride (Merck Bulgaria EAD, Sofia, Bulgaria). For this purpose, a Stomacher 400 Circulator (Seward Limited, Worthing, West Sussex, United Kingdom) was used. The samples were decimally diluted $\left(10^{-8}\right)$. The Micrococcus-Staphylococcus spp. count was determined after 48 -h incubation at $37^{\circ} \mathrm{C}$ on Baird Parker agar (Oxford, Basingstoke, UK) combined with 3.5\% egg yolk telluride emulsion [Ensoy et al., 2010]. The lactic acid bacteria count was estimated after 48 -h incubation at $37^{\circ} \mathrm{C}$ on MRS agar [Komprada et al., 2004]. The total mesophilic aerobic bacteria count was determined after 72-h incubation at $28^{\circ} \mathrm{C}$ [Gelabert et al., 2003], and the count of yeast - after the same type incubation on potato-dextrose agar Merck 1.10130 (Merck Bulgaria EAD, Sofia, Bulgaria) [Coppola et al., 2000].

\section{Statistical analysis}

All the analyses were replicated nine times $(n=9)$. Results were expressed as means \pm standard deviation (SD). Statistical analyses were conducted using SPSS 11.0 software (SPSS Inc., Chicago, Illinois, USA). Data were analyzed independently by ANOVA software (Excel 5.0). The Duncan multiple comparison test was used to determine differences between the mean values. If $p$-values for the differences among the means were less than 0.05 , they were considered statistically significant.

\section{RESULTS AND DISCUSSIONS}

\section{Sensory analysis}

On the $14^{\text {th }}$ day of the experiment the highest score for the surface of a sectional view was given to samples $\mathrm{E}$ $\left(\mathrm{p}^{*}<0.05\right)$, followed by samples $\mathrm{R}(3 \mathrm{~g} / \mathrm{kg}$ ground black pepper, $3 \mathrm{~g} / \mathrm{kg}$ ground cumin and $0.2 \mathrm{~g} / \mathrm{kg}$ rosemary) and B ( $3 \mathrm{~g} / \mathrm{kg}$ ground black pepper, $3 \mathrm{~g} / \mathrm{kg}$ ground cumin and $0.2 \mathrm{~g} /$ $\mathrm{kg}$ BHT) which were not significantly $\left(\mathrm{p}^{*}>0.05\right)$ different among themselves (Table 1). The highest score for color was awarded in the sensory assessment to the samples E (containing aliquots of extracts from $3 \mathrm{~g} / \mathrm{kg}$ black pepper and $3 \mathrm{~g} /$ $\mathrm{kg}$ cumin) $\left(\mathrm{p}^{*}<0.05\right)$. The color of the other samples did not differ significantly $\left(\mathrm{p}^{*}>0.05\right)$. Their sensory scores varied 
TABLE 3. Proximate composition of the dry-cured sausages "Sudjuk" during processing, after manufacturing and after 30 days of storage at $0-4{ }^{\circ} \mathrm{C}$.

\begin{tabular}{|c|c|c|c|c|c|}
\hline Samples & $\begin{array}{c}\text { Moisture } \\
(\%)\end{array}$ & $\begin{array}{c}\text { Total protein } \\
(\%)\end{array}$ & $\begin{array}{l}\text { Total lipids } \\
(\%)\end{array}$ & $\begin{array}{c}\text { Minerals } \\
(\%)\end{array}$ & $\begin{array}{c}\text { Carbohydrates } \\
(\%)\end{array}$ \\
\hline \multicolumn{6}{|c|}{$\begin{array}{l}\text { Proximate composition of the samples on the } 1^{\text {st }} \text { day of experiment } \\
\text { (sausages filling mass) }\end{array}$} \\
\hline $\mathrm{C}$ & $56.72^{\mathrm{e}} \pm 0.15$ & $16.18^{\mathrm{a}} \pm 0.17$ & $24.94^{a} \pm 0.59$ & $1.02^{\mathrm{a}} \pm 0.11$ & $1.14^{c} \pm 0.12$ \\
\hline $\mathrm{E}$ & $56.72^{\mathrm{e}} \pm 0.15$ & $16.18^{\mathrm{a}} \pm 0.17$ & $24.94^{\mathrm{a}} \pm 0.59$ & $1.02^{\mathrm{a}} \pm 0.11$ & $1.14^{c} \pm 0.12$ \\
\hline B & $56.72^{\mathrm{e}} \pm 0.15$ & $16.18^{\mathrm{a}} \pm 0.17$ & $24.94^{\mathrm{a}} \pm 0.59$ & $1.02^{\mathrm{a}} \pm 0.11$ & $1.14^{c} \pm 0.12$ \\
\hline $\mathrm{R}$ & $56.72^{\mathrm{e}} \pm 0.15$ & $16.18^{\mathrm{a}} \pm 0.17$ & $24.94^{\mathrm{a}} \pm 0.59$ & $1.02^{\mathrm{a}} \pm 0.11$ & $1.14^{c} \pm 0.12$ \\
\hline $\mathrm{T}$ & $56.72^{\mathrm{e}} \pm 0.15$ & $16.18^{\mathrm{a}} \pm 0.17$ & $24.94^{\mathrm{a}} \pm 0.59$ & $1.02^{\mathrm{a}} \pm 0.11$ & $1.14^{\mathrm{c}} \pm 0.12$ \\
\hline \multicolumn{6}{|c|}{$\begin{array}{l}\text { Proximate composition of the samples on the } 14^{\text {th }} \text { day of experiment } \\
\text { (Sudjuk immediately after manufacturing) }\end{array}$} \\
\hline $\mathrm{C}$ & $30.56^{\mathrm{b}} \pm 0.22$ & $25.27^{\mathrm{b}} \pm 0.21$ & $37.56^{\mathrm{e}} \pm 0.61$ & $5.80^{c} \pm 0.17$ & $0.81^{\mathrm{b}} \pm 0.11$ \\
\hline E & $35.22^{\mathrm{d}} \pm 0.20$ & $25.53^{c} \pm 0.24$ & $33.30^{b} \pm 0.55$ & $5.24^{b} \pm 0.15$ & $0.71^{\mathrm{b}} \pm 0.16$ \\
\hline B & $30.85^{b} \pm 0.13$ & $25.71^{\mathrm{c}} \pm 0.23$ & $36.78^{\mathrm{d}} \pm 0.70$ & $5.94^{c} \pm 0.21$ & $0.72^{b} \pm 0.19$ \\
\hline $\mathrm{R}$ & $32.77^{\mathrm{c}} \pm 0.12$ & $25.84^{c} \pm 0.20$ & $34.76^{\mathrm{c}} \pm 0.64$ & $5.78^{\mathrm{c}} \pm 0.19$ & $0.85^{\mathrm{b}} \pm 0.21$ \\
\hline $\mathrm{T}$ & $30.53^{b} \pm 0.16$ & $26.58^{\mathrm{d}} \pm 0.27$ & $36.42^{\mathrm{d}} \pm 0.66$ & $5.82^{\mathrm{c}} \pm 0.18$ & $0.65^{b} \pm 0.10$ \\
\hline \multicolumn{6}{|c|}{$\begin{array}{l}\text { Proximate composition of the samples on the } 44^{\text {th }} \text { day of experiment } \\
\text { (Sudjuk refrigeration stored } 30 \text { days after production) }\end{array}$} \\
\hline $\mathrm{C}$ & $30.67^{b} \pm 0.19$ & $25.38^{b} \pm 0.24$ & $37.67^{e} \pm 0.73$ & $5.83^{\mathrm{c}} \pm 0.18$ & $0.45^{\mathrm{a}} \pm 0.09$ \\
\hline $\mathrm{E}$ & $35.51^{\mathrm{d}} \pm 0.22$ & $25.66^{\mathrm{c}} \pm 0.31$ & $32.95^{b} \pm 0.66$ & $5.28^{b} \pm 0.16$ & $0.60^{\mathrm{a}, \mathrm{b}} \pm 0.11$ \\
\hline B & $30.99^{b} \pm 0.27$ & $25.59^{c} \pm 0.28$ & $36.91^{\mathrm{d}} \pm 0.75$ & $5.96^{c} \pm 0.22$ & $0.55^{\mathrm{a}} \pm 0.08$ \\
\hline $\mathrm{R}$ & $32.87^{\mathrm{c}} \pm 0.18$ & $25.73^{\mathrm{c}} \pm 0.27$ & $35.02^{\mathrm{c}} \pm 0.69$ & $5.84^{c} \pm 0.20$ & $0.54^{\mathrm{a}} \pm 0.10$ \\
\hline $\mathrm{T}$ & $30.56^{\mathrm{b}} \pm 0.17$ & $26.62^{\mathrm{d}} \pm 0.33$ & $36.39^{\mathrm{d}} \pm 0.71$ & $5.89^{c} \pm 0.16$ & $0.54^{\mathrm{a}} \pm 0.09$ \\
\hline
\end{tabular}

Sample description as under Table 1 . The data for $14^{\text {th }}$ day and $44^{\text {th }}$ day were analyzed with the same ANOVA analysis. Data were expressed as Mean $\pm \mathrm{SD}(\mathrm{n}=9)$, a, b, c, d, - Means in the column with different subscript letters are significantly different $(\mathrm{p} \leq 0.05)$.

between 7.61 and 7.70. These results allow us to conclude that the color of the "Sudjuk" with the addition of the examined antioxidants, evaluated in the sensory analysis, does not influence the sensory-assessed color characteristics of the samples. Similarly to our findings, Barbut et al. [1985] established a good effect of rosemary oleoresin on the quality and storage stability of turkey sausages and a slight effect of BHT addition.

The addition of black pepper and cumin extracts improved the consistence of dry-cured sausages, too. The scores obtained for samples $\mathrm{E}$ were the highest and significantly $\left(\mathrm{p}^{*}<0.05\right)$ different compared to samples C (control, $3 \mathrm{~g} / \mathrm{kg}$ ground black pepper, $3 \mathrm{~g} / \mathrm{kg}$ ground cumin), B, R and T (ground black pepper $3 \mathrm{~g} / \mathrm{kg}$, ground cumin and $0.2 \mathrm{~g} / \mathrm{kg}$ DHQ) (Table 1). The consistence of the "Sudjuk" was slightly affected by the addition of $\mathrm{R}, \mathrm{B}$ and $\mathrm{T}$.

The highest score for taste was found in samples $\mathrm{R}$ $\left(p^{*}<0.05\right)$. The addition of R, B, T and black pepper and cumin extracts increased the taste sensory scores by $17-22 \%$.

The addition of $0.2 \mathrm{~g} / \mathrm{kg}$ rosemary extract (sample $\mathrm{R}$ ) was as effective as the addition of freon extracts (sample E) on the overall acceptability on the $14^{\text {th }}$ day. The highest overall acceptability sensory score $\left(\mathrm{p}^{*}<0.05\right)$ on the $44^{\text {th }}$ day of the experiment, was awarded to the samples E. In comparison to the control sample $(\mathrm{C})$, the addition of black pepper and cumin extracts improved the overall acceptability of dry-cured sausages by $15-16 \%\left(\mathrm{p}^{*}<0.05\right)$. The slight, but statistically significant positive effect with $10 \%$ and $8.1 \%$ improvement on overall acceptability was established after rosemary extract (samples $\mathrm{R}-3 \mathrm{~g} / \mathrm{kg}$ ground black pepper, $3 \mathrm{~g} / \mathrm{kg}$ ground cumin and $0.2 \mathrm{~g} \mathrm{~g} / \mathrm{kg}$ rosemary) and BHT (samples B - $3 \mathrm{~g} / \mathrm{kg}$ ground black pepper, $3 \mathrm{~g} / \mathrm{kg}$ ground cumin and $0.2 \mathrm{~g} / \mathrm{kg}$ BHT) addition, respectively $\left(\mathrm{p}^{*}<0.05\right)$ (Table 1). After the $30^{\text {th }}$ day of refrigeration storage, the highest numerical scores for the surface of a sectional view were given to samples B $\left(p^{*}<0.05\right)$ (Table 1$)$. Similarly, the highest scores for color and consistence were awarded to sample $\mathrm{E}\left(\mathrm{p}^{*}<0.05\right)$. The use of black pepper and cumin extracts can stabilize the "Sudjuk" color and preserve its consistence during 30 days of storage at $0-4^{\circ} \mathrm{C}$. The addition of $0.2 \mathrm{~g} / \mathrm{kg}$ butylated hydroxytoluene (B) is also as effective as the addition of E during 30 days of storage for the surface of the sectional view. The different solvents used in extraction contribute to retrieval of the various types and amounts of active herb ingredients and, therefore, each extract has a specific effect on the product [Marco et al., 2004; Velasco \& Williams, 2011].

The lowest taste scores were evaluated in samples $\mathrm{R}$ after 30 days of storage of vacuum packed "Sudjuk" at $0-4^{\circ} \mathrm{C}$. The addition of rosemary extract deteriorated the taste 
TABLE 4. Microbiological analysis of the aerobic plate counts, E. coli counts, and the incidence of Salmonella spp. and L. monocytogenes for studied samples of dry-cured sausages "Sudjuk" during processing, after manufacturing and 30 days of storage at $0-4^{\circ} \mathrm{C}$.

\begin{tabular}{|c|c|c|c|c|}
\hline Samples & $\begin{array}{l}\text { Total mesophilic aerobic bacteria } \\
\log _{10} \mathrm{cfu} / \mathrm{g}\end{array}$ & $\begin{array}{l}\text { Lactic acid bacteria } \\
\log _{10} \mathrm{cfu} / \mathrm{g}\end{array}$ & $\begin{array}{l}\text { Micrococcus-Staphylococcus spp. } \\
\log _{10} \text { cfu/g }\end{array}$ & $\begin{array}{c}\text { Count of yeast } \\
\log _{10} \mathrm{cfu} / \mathrm{g}\end{array}$ \\
\hline \multicolumn{5}{|c|}{$\begin{array}{c}\text { Microbiological status of the samples on the } 1^{\text {st }} \text { day of experiment } \\
\text { (sausages filling mass) }\end{array}$} \\
\hline $\mathrm{C}$ & $5.23^{\mathrm{a}} \pm 0.11$ & $4.33^{\mathrm{a}} \pm 0.32$ & $4.59^{\mathrm{a}} \pm 0.33$ & $5.29^{\mathrm{a}} \pm 0.31$ \\
\hline E & $5.13^{\mathrm{a}} \pm 0.08$ & $4.48^{\mathrm{a}} \pm 0.27$ & $4.51^{\mathrm{a}} \pm 0.32$ & $5.02^{\mathrm{a}} \pm 0.37$ \\
\hline B & $5.20^{\mathrm{a}} \pm 0.05$ & $4.51^{\mathrm{a}} \pm 0.28$ & $4.56^{\mathrm{a}} \pm 0.39$ & $5.22^{\mathrm{a}} \pm 0.33$ \\
\hline $\mathrm{R}$ & $5.19^{\mathrm{a}} \pm 0.07$ & $4.40^{\mathrm{a}} \pm 0.33$ & $4.55^{\mathrm{a}} \pm 0.31$ & $5.25^{\mathrm{a}} \pm 0.36$ \\
\hline $\mathrm{T}$ & $5.17^{\mathrm{a}} \pm 0.09$ & $4.34^{\mathrm{a}} \pm 0.31$ & $4.54^{\mathrm{a}} \pm 0.30$ & $5.27^{\mathrm{a}} \pm 0.34$ \\
\hline \multicolumn{5}{|c|}{$\begin{array}{c}\text { Microbiological status of the samples on the } 14^{\text {th }} \text { day of experiment } \\
\text { (Sudjuk immediately after manufacturing) }\end{array}$} \\
\hline $\mathrm{C}$ & $8.13^{\mathrm{c}} \pm 0.29$ & $7.92^{c} \pm 0.36$ & $7.66^{c} \pm 0.33$ & $6.89^{c} \pm 0.36$ \\
\hline E & $7.24^{b} \pm 0.27$ & $7.04^{b} \pm 0.19$ & $6.95^{b} \pm 0.17$ & $6.26^{b} \pm 0.16$ \\
\hline B & $7.97^{c} \pm 0.31$ & $7.41^{c} \pm 0.21$ & $7.34^{\mathrm{c}} \pm 0.35$ & $6.77^{\mathrm{c}} \pm 0.24$ \\
\hline $\mathrm{R}$ & $8.02^{\mathrm{c}} \pm 0.30$ & $7.77^{c} \pm 0.28$ & $7.44^{\mathrm{c}} \pm 0.37$ & $6.67^{c} \pm 0.20$ \\
\hline $\mathrm{T}$ & $8.20^{\mathrm{c}} \pm 0.28$ & $7.89^{c} \pm 0.33$ & $7.51^{\mathrm{c}} \pm 0.21$ & $6.70^{c} \pm 0.23$ \\
\hline \multicolumn{5}{|c|}{$\begin{array}{l}\text { Microbiological status of the samples samples on the } 44^{\text {th }} \text { day of experiment } \\
\text { (Sudjuk refrigeration stored } 30 \text { days after production) }\end{array}$} \\
\hline $\mathrm{C}$ & $8.44^{\mathrm{e}} \pm 0.34$ & $8.27^{\mathrm{e}} \pm 0.29$ & $6.57^{\mathrm{e}} \pm 0.29$ & $7.31^{\mathrm{e}} \pm 0.18$ \\
\hline $\mathrm{E}$ & $7.82^{\mathrm{d}} \pm 0.21$ & $7.22^{\mathrm{d}} \pm 0.18$ & $5.99^{\mathrm{d}} \pm 0.27$ & $6.23^{\mathrm{d}} \pm 0.17$ \\
\hline B & $8.40^{\mathrm{e}} \pm 0.32$ & $8.16^{\mathrm{e}} \pm 0.26$ & $6.66^{\mathrm{e}} \pm 0.30$ & $7.46^{\mathrm{e}} \pm 0.36$ \\
\hline $\mathrm{R}$ & $8.50^{\mathrm{e}} \pm 0.36$ & $8.14^{\mathrm{e}} \pm 0.27$ & $6.64^{\mathrm{e}} \pm 0.33$ & $7.44^{\mathrm{e}} \pm 0.35$ \\
\hline $\mathrm{T}$ & $8.39^{\mathrm{e}} \pm 0.29$ & $8.02^{\mathrm{e}} \pm 0.22$ & $6.72^{\mathrm{e}} \pm 0.32$ & $7.32^{\mathrm{e}} \pm 0.24$ \\
\hline
\end{tabular}

Sample description as under Table 1 . The data for $14^{\text {th }}$ day and $44^{\text {th }}$ day were analyzed with the same ANOVA analysis. Data were expressed as Mean $\pm \mathrm{SD}(\mathrm{n}=9)$. $\mathrm{a}, \mathrm{b}, \mathrm{c}, \mathrm{d}, \mathrm{e}-$ Means in the column with different subscript letters are significantly different $(\mathrm{p} \leq 0.05)$.

of "Sudjuk". According to the panel members, stabilizing and more acceptable taste was achieved through the addition of BHT and black pepper and cumin extracts, while the addition of taxifolin did not influence these sensory characteristics. In comparison to the control sample, the BHT, rosemary and taxifolin improved the overall acceptability by $11.7 \%$, $11.6 \%$ and $11.3 \%\left(\mathrm{p}^{*}<0.05\right)$. The addition of black pepper and cumin extracts improved by $27-28 \%$ the overall acceptability of the dry-cured sausages.

\section{Color characteristics}

The color characteristics $\left(\mathrm{L}^{*}, \mathrm{a}^{*}, \mathrm{~b}^{*}\right)$ corresponded to the results obtained from sensory analysis of dry-cured sausages "Sudjuk". The $\mathrm{L}^{*}$ values were in a wide range in all samples (19.55-42.60). On the $7^{\text {th }}$ day of the experiment, the color brightness $\left(\mathrm{L}^{*}\right)$ of four of the samples, especially in samples $\mathrm{B}$, was higher than this of the control samples C. On the $14^{\text {th }}$ day of the experiment, $\mathrm{L}^{*}$ value of samples $\mathrm{C}$ and $\mathrm{E}$ increased, while those in other three samples B, T and R decreased (Table 2). A statistically significant $\left(p^{*}<0.05\right)$ decrease of $L^{*}$ value in all five samples was established on the $44^{\text {th }}$ day of the experiment. Compared to samples $\mathrm{C}$ and $\mathrm{B}$, color brightness of the other three samples was lower.

The red color component $\left(\mathrm{a}^{*}\right)$ in samples E decreased significantly $\left(\mathrm{p}^{*}<0.05\right)$ during "Sudjuk" manufacturing pro- cess (to the $14^{\text {th }}$ day of the experiment). In opposite, a little increase in $a^{*}$ values $\left(p^{*}>0.05\right)$ was established in samples $\mathrm{B}$ and $\mathrm{R}$. The addition of $0.2 \mathrm{~g} / \mathrm{kg}$ taxifolin (samples $\mathrm{T}$ ) increased by $5.5 \%\left(\mathrm{p}^{*}<0.05\right)$ the red color component $\left(\mathrm{a}^{*}\right)$ on the $14^{\text {th }}$ day of the experiment (Table 2). On the $44^{\text {th }}$ day of the experiment, significantly $\left(\mathrm{p}^{*}<0.05\right)$ higher $\mathrm{a}^{*}$ values were determined in samples $E$. The red color component ( $\left.\mathrm{a}^{*}\right)$ of samples E was by 14.9-25.5\% higher in comparison with those estimated in samples B, T, and R (Table 2). Our results are similar to those reported by Djenane et al. [2002] who determined the enhancement of meat red color by delaying metmyoglobin formation when rosemary and L-ascorbic acid were used.

On the $7^{\text {th }}$ day of the experiment, $b^{*}$ value of samples $E$ was the highest. During the production process it decreased significantly $\left(p^{*}<0.05\right)$ by approx. $30 \%$, and on the $14^{\text {th }}$ day of the experiment (final product) was the lowest. Thereafter on the $44^{\text {th }}$ day of the experiment (after 30 days refrigeration storage), the yellow color component $\left(b^{*}\right)$ of samples $E$ increased again, and had higher values by 16.6-35.2\% compared to the other four samples (Table 2). During sausage production, the yellow color component $\left(\mathrm{b}^{*}\right)$ of samples $\mathrm{B}, \mathrm{R}$ and $\mathrm{T}$ was comparatively stable $\left(\mathrm{p}^{*}>0.05\right)$, but after 30 days of refrigeration storage (on the $44^{\text {th }}$ day of the experiment) it increased significantly $\left(\mathrm{p}^{*}<0.05\right)$ by $17.4-25.5 \%$. 


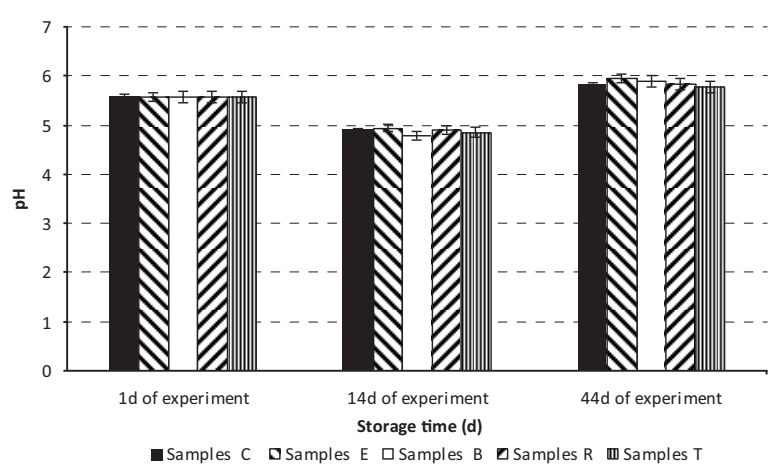

FIGURE 2. pH value of the dry-cured sausages "Sudjuk" during processing (1d of experiment), after manufacturing (14d of experiment) and after 30 days of storage at $0-4^{\circ} \mathrm{C}$ ( $44 \mathrm{~d}$ of experiment).

C-control sample with $3 \mathrm{~g} / \mathrm{kg}$ of ground black pepper (Piper nigrum $L$.) and cumin (Cuminum cyminum); E- test sample with freon extracts of ground black pepper (Piper nigrum L.), and cumin (Cuminum cyminum); B- test sample with $3 \mathrm{~g} / \mathrm{kg}$ of ground black pepper (Piper nigrum $L$.), and cumin (Cuminum cyminum) and $0.2 \mathrm{~g} / \mathrm{kg}$ butylated hydroxytoluene addition; R- test sample with $3 \mathrm{~g} / \mathrm{kg}$ of ground black pepper (Piper nigrum L.), and cumin (Cuminum cyminum) and $0.2 \mathrm{~g} / \mathrm{kg}$ rosemary (Rosmarinus officinalis $L$.) extract addition; T- test sample with $3 \mathrm{~g} / \mathrm{kg}$ of ground black pepper (Piper nigrum L.), and cumin (Cuminum cyminum) and $0.2 \mathrm{~g} / \mathrm{kg}$ taxifolin extract from Siberian larch (Larix sibirica Ledeb) addition.

\section{Proximate composition}

The moisture content in all samples decreased significantly $\left(\mathrm{p}^{*}<0.05\right)$ during "Sudjuk" production, and the dry matter increased respectively (Table 3 ). The contents of moisture and dry matter of the final product were stable and not significantly $\left(p^{*}>0.05\right)$ different throughout the 30 -day storage period. The changes in dry matter were directly related to the content of proteins, lipids and minerals. During dry-cured sausages' processing values of those indicators increased significantly $\left(\mathrm{p}^{*}<0.05\right)$ (Table 3$)$. Only carbohydrate content decreased statistically $\left(\mathrm{p}^{*}<0.05\right)$ during "Sudjuk" processing and storage. This was associated with the cultivation of the applied starter culture of lactic acid bacteria that degrade the carbohydrates as a substrate for their development.

It is obvious that drying and 'ripening' lead to a decrease in sausages moisture and respectively to an increase in contents of protein, lipid and ash in the end product. Those changes occur irrespectively of the applied spice extracts or antioxidants, and can be connected with higher acidity thus influencing the water holding capacity of the meat. These results were confirmed by the data obtained for the $\mathrm{pH}$ value of the dry-cured sausages (Figure 2).

\section{Free amino nitrogen and $\mathrm{pH}$ value}

The changes in $\mathrm{pH}$ value were not affected by the type of spice extracts and antioxidants used during sausage production (Figure 2). Identified changes were typical for this type of meat products [Balev et al., 2005; Hughes et al., 2002].

At the $14^{\text {th }}$ day of processing, the hydrolysis in protein fraction decreased 1.41 and 1.53 times in sausages with $0.2 \mathrm{~g} / \mathrm{kg}$ rosemary $(\mathrm{R})$ and $0.2 \mathrm{~g} / \mathrm{kg}$ taxifolin (T) addition (Figure 3). On the $44^{\text {th }}$ day of the experiment, the lowest free amino nitrogen content $\left(\mathrm{p}^{*}<0.05\right)$ was established in samples R (3 g/kg of ground black pepper (Piper nigrum L.),

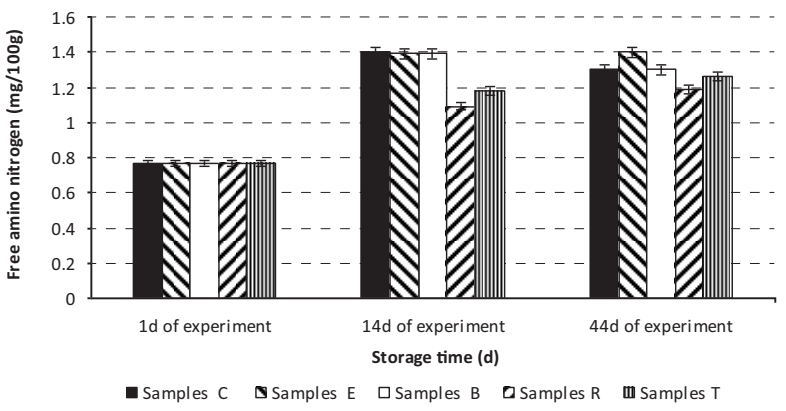

FIGURE 3. Free amino nitrogen content in the dry-cured sausages "Sudjuk" during processing (1d of experiment), after manufacturing (14d of experiment) and 30 days of storage at $0-4^{\circ} \mathrm{C}$ ( $44 \mathrm{~d}$ of experiment)

Sample description as under Figure 2.

cumin (Cuminum cyminum) and $0.2 \mathrm{~g} / \mathrm{kg}$ rosemary (Rosmarinus officinalis $L$.) extract) followed by samples $\mathrm{T}(3 \mathrm{~g} / \mathrm{kg}$ of ground black pepper (Piper nigrum L.), cumin (Cuminum cyminum) and $0.2 \mathrm{~g} / \mathrm{kg}$ taxifolin extract from Siberian larch). We can conclude that the changes in free amino nitrogen were not affected by the type of spice extract, but the addition of antioxidants as $0.2 \mathrm{~g} / \mathrm{kg}$ rosemary or $0.2 \mathrm{~g} / \mathrm{kg}$ taxifolin inhibits the hydrolysis in the studied dry-cured sausages (Figure 3).

\section{Microbiological characteristics}

The results from microbiological analysis showed that the total mesophilic aerobic bacteria count, lactic acid bacteria count, the count of Micrococcus-Staphylococcus spp., and yeast did not change significantly $(p>0.05)$ (Table 4$)$. Exception of those results was only found for samples $\mathrm{E}$ (Table 4) independently of the processing or storage stage. This means that the replacement of freon spice extracts has a stronger antimicrobial activity in comparison to natural ground spices. Our findings confirmed results obtained by Dobreva et al. [2009] who found that the extracts of black pepper and cumin had a highly antimicrobial activity against Gram-positive than Gram-negative bacteria. Similar microbiological changes to our results were reported by Ensoy et al. [2010] when the Turkish sucuk was studied.

\section{CONCLUSIONS}

The results and their analysis allow us to conclude that the stabilized and more acceptable flavor (aroma and taste) was achieved through the addition of BHT and black pepper and cumin extracts while the addition of taxifolin did not influence these sensory characteristics. The addition of $0.2 \mathrm{~g} / \mathrm{kg}$ rosemary extract was as effective as the addition of freon extracts on the overall acceptability to the $14^{\text {th }}$ day of experiment. The replacement of ground natural spices (black pepper and cumin grain) with aliquots of their freon extracts enhanced the color characteristics $\left(L^{*}, a^{*}, b^{*}\right)$ and sensory properties of dry-cured sausages stored at $0-4^{\circ} \mathrm{C}$ for 30 days. The investigated new spice freon extracts can be successfully used to improve the quality of Bulgarian-type dry-cured sausages "Sudjuk". 


\section{RESEARCH FUNDING}

This work has not financial relationships with sponsoring organizations and any commercial or financial involvements that might represent an appearance of a conflict of interest.

\section{CONFLICT OF INTEREST}

Authors declare no conflict of interest.

\section{REFEERENCES}

1. Bakalivanova T., Kaloyanov N., Effect of taxifolin, rosemary and synthetic antioxidants treatment on the mechanically separated poultry meat lipid peroxidation. Oxid. Commun., 2014, 37, 254-261.

2. Balev D., Vulkova T., Dragoev S., Zlatanov M., Bahtchevanska S., A comparative study on the effect of some antioxidants on the lipid and pigment oxidation in dry fermented sausages. Int. J. Food Sci. Technol., 2005, 40, 977-983.

3. Barbut S., Josephson, D.B., Maurer A.J., Antioxidant properties of rosemary oleoresin in Turkey sausage. J. Food Sci., 1985, 50, 1356-1359.

4. Cabeza M.C., de la Hoz L., Velasco R., Cambero M.I., Ordóñez J.A., Safety and quality of ready-to-eat dry fermented sausages subjected to E-beam radiation. Meat Sci., 2009, 83, 320-327.

5. Coppola S., Mauriello G., Aponte M., Moschetti G., Villani F., Microbial succession during ripening of Naples-type salami, a southern Italian fermented sausage. Meat Sci., 2000, 56, $321-$ -329 .

6. Curt C., Hossenlopp J., Perrot N., Trystram G., Dry sausage ripening control integration of sensory-related properties. Food Contr., 2002, 13, 151-159.

7. Djenane D., Sánchez-Escalante A., Beltrán J.A., Roncalés P., Ability of $\alpha$-tocopherol, taurine and rosemary, in combination with vitamin $\mathrm{C}$, to increase the oxidative stability of beef steaks packaged in modified atmosphere. Food Chem., 2002, 76, 407-415 .

8. Dobreva K., Boitcheva S., Gotchev V., Stoyanova A., Antimicrobial activity of extracts from spice mixes. Trakia J. Sci., 2009, 7, 191-195 (in Bulgarian; English abstract).

9. Dorman H.J.D., Deans S.G., Antimicrobial agents from plants: antibacterial activity of plant volatile oils. J. Appl. Microbiol. 2000, 88, 308-316.

10. Ensoy U., Kolsarici N., Candogan K., Karslioglu B., Changes in biochemical and microbiological characteristics of Turkey sucuks as affected by processing and starter culture utilization. J. Muscle Foods, 2010, 21, 142-165.

11. Fasseas M.K., Mountzouris K.C., Tarantilis P.A., Polissiou M., Zervas G., Antioxidant activity in meat treated with oregano and sage essential oils. Food Chem., 2008, 106, 1188-1194.

12. Hughes M.C., Kerry J.P., Arendt E.K., Kenneally P.M., McSweeney P.L.H., O'Neill E.E., Characterization of proteolysis during the ripening of semi-dry fermented sausages. Meat Sci., 2002, $62,205-216$.

13. Hunt M., King A., Barbut Sh., Claus J., Cornforth D., Hanson D., Section VIII. Guidelines, instrumental meat colour measurement. 2012. in: AMSA Meat Colour Measurement Guidelines (eds. M. Hunt, A. King). Champaign, Il: American Meat Science Association, pp. 45-260.

14. Gelabert J., Gou P., Gerrero L., Arnau G., Effect of sodium chloride on some characteristics of fermented sausages. Meat Sci., 2003, 65, 833-839.

15. Jensen W.B., The origin of the Soxhlet extractor. J. Chem. Educ., 2007, 84, 1913-1917.

16. King B.M., Sebranek J.G., Combustion method for determination of crude protein in meat and meat products: collaborative study. J. AOAC Int., 1993, 76, 787-793.

17. Kirkbright G.F., Mayne P.J., West T.S., Technical note: Application of a permittivity method for the rapid determination of water in meat. Int. J. Food Sci. Technol., 1975, 10, 103-108.

18. Komprada T., Smela D., Pechova P., Kalhotka L., Strench J., Klejdus B., Effect of starter culture, spice mix and storage time and temperature on biogenic amine content of dry-fermented sausages. Meat Sci., 2004, 67, 607-616.

19. Marco A., Navarro J.L., Flores M., Volatile compounds of drycured sausages as affected by solid-phase micro extraction (SPME). Food Chem., 2004, 84, 633-641.

20. Meilgaard M.C., Carr B.T., Civill G.V., Selection and training of panel members. 2006. in: Sensory Evaluation Techniques. Fourth Edition. (eds. M.C. Meilgaard, B.T. Carr, G.V. Civill). Boca Raton: CRC Press LLC, Taylor and Francis Group, pp. 133-159.

21. Misharina T.A., Andreenkov V.A., Vashchuk E.A., Changes in the composition of volatile compounds during aging of drycured sausages. Appl. Biochem. Microbiol., 2001, 37, 413-418.

22. Nenov N., Extraction of plant materials with liquefied gases. Part 1 - Laboratory installation. Scientific works volume LIII "Food science, engineering and technologies", 2006, pp. 195-200 (in Bulgarian; English abstract).

23. Rohlik B.-O., Pipek P., Rosemary extract and its effect on meat products' properties. Fleischwirtschaft, 2013, -93, 98-104.

24. Stojković D., Petrović J., Soković M., Glamočlija J., KukićMarković J., Petrović S., In situ antioxidant and antimicrobial activities of naturally occurring caffeic acid, p-coumaric acid and rutin, using food systems. J. Sci. Food Agric., 2013, 93, 3205-3208.

25. Suhaj M., Spice antioxidants isolation and their antiradical activity: A review. J. Food Comp. Anal., 2006, 19, 531-537.

26. Tešanović D., Kalenjuk B., Tešanović D., Psodorov Đ., Ristić Z., Marković. V., Changes of biochemical and sensory characteristics in the muscles longissimus dorsi of the fallow deer in the early phase post-mortem and during maturation. Afr. J. Biotechnol., 2011, 10, 11668-11675.

27. Van Esch G.J., Toxicology of tert-butylhydroquinone (TBHQ). Food Chem. Toxicol., 1986, 24, 1063-1065.

28. Velasco V., Williams P., Improving meat quality through natural antioxidants. Review. Chil. J. Agric. Res., 2011, 71, 313-322.

29. Young O.A., West J., Hart A.L., van Otterdijk F.F.H., A method for early determination of meat ultimate $\mathrm{pH}$. Meat Sci., 2004, 66, 493-498.

30. Zanardi E., Dorigoni V., Badiani A., Chizzolini R., Lipid and colour stability of Milano-type sausages: Effect of packing conditions. Meat Sci., 2002, 61, 7-14.

Submitted: 24 March 2015. Revised: 13 October and 16 October 2015, 22 February and 22 April 2016. Accepted: 9 May 2016. Published on-line: 5 October 2016. 